Nippon Suisan Gakkaishi $\quad$ 82(5), 821 (2016)

\title{
ミニシンポジウム記録エリアケイパビリティーアプローチによる漁村開発
}

\section{3. フィリピン国バタン湾における“つくる漁業” とエリアケイパビリティーの向上}

\author{
黒倉 寿 \\ 東京大学大学院農学生命科学研究科
}

3. Area capability enhancement and

"Tsukuru-gyogyo" (culture based fisheries)

in Batan Bay, Philippines

HISASHI KUROKURA

Graduate School of Agricultural and Life Sciences, The University of Tokyo, Bunkyo-ku, Tokyo 113-8657, Japan

\section{I．漁業管理に関する最近の議論}

共有資源の競争的な利用の結果，資源の過㮃利用を招 き，資源が崩壊する現象を，「共有地の悲劇」1)という。 かつて,「共有地の悲劇」を避けるための方法として, 所有権の明確化が必要とされ，そのために，政府による 解決をたは市場による解決が行有効とされた。政府によ る解決とは行政による規制・管理施策であり，市場によ る解決とは, 所有権の市場取引である。2 つの解決を原 理主義的に経済用語に置き換えるとすれば，国家による 計画経済と市場経済と整理できるが，この二つは打互い 相いれない正反対のベクトルを持つものではないだろ う。市場による解決の合理性が強調されがちであるが, 市場の失敗の例も少なからずあり，適切な行政の関与は 必要である。最近では, 配分の合理性の中に公平性, 弱 者への配慮等の倫理性等の議論も重要になっている。一 方, 里山や沿岸漁業資源などの地域環境や資源は一般的 な共有物（commons）ではなく, 地域共有物（local commons）とする考え方も一般化しつつある。この考 え方では, 行政の関与の下で，地域住民が地域の合意に 基づいて管理システムの構築と管理に参画していことが 理想的であろう。こうした， co-management の成功に は, 行政の適切な関与, 情報の提供, 地域の合意形成シ ステム, リーダーシップ等々様々要因が関係し, 成功要 因の分析も行われている。㞷特に社会インフラが未整備 な途上国においては，地域住民が持つ地域資源や環境に 対する知識と管理・利用に対する積極的な参加意欲はと りわけ重要である。

\section{II. エリアケイパビリティー（AC）と「つくる漁業」}

2003 年に「日本栽培漁業協会」が独立行政法人水産 総合研究センターに統合されるなど,「栽培漁業」は縮
小傾向にある。「栽培漁業」には, 費用対効果や天然資 源の遺伝的な攪乱など批判も多い。「栽培漁業」が推進 されてきた背景には，仔稚魚の生育環境の破壊に対する 補償としての意味もあった。漁業者の人口が減少し, 多 くの沿岸漁業社会が消滅に向かう現状にあっては, その 縮小やむを得ない。「栽培漁業」は，放流という特定の 技術を意味するものと䛊解されがちであるが，本来は大 島康雄が提唱した「つくる漁業」3)の一つの実践事業で ある。「つくる漁業」とは, 漁業者自身が資源の増殖・ 維持・管理に積極的にかかわることであり, 放流事業だ けではなく, 資源の生育環境の維持・造成や, 適切な漁 業規制管理など様々な技術があり, 放流事業はその一部 に過ぎない。「つくる漁業」は理念であり啓蒙である。 $\mathrm{AC}$ プロジェクトでは, 参加型の種苗放流事業が, 漁業 者の資源管理に対する参加動機を創出する効果があると いう仮説に基づいて, フィリピン・バタン湾において, ウシエビの放流事業を実施し, 住民の意識変化を含む効 果を追跡している。

\section{III. フィリピン・バタン湾におけるウシエビ放流事業}

プロジェクトの実施前, 打よび実施期間中に, 地元住 民及び行政に対する説明を数回行った。また, 中間育成 池の造成, 中間育成の実施は, 地元漁業者組織のボラン ティアに打願いした。環境調査は, $\mathrm{AC}$ プロジェクトと フィリピン大学ビザヤ校が協力して行い, 生態抢よび採 捕率の調查は, 地元漁業者の協力を得て, 東南アジア漁 業開発センター養殖部局 $(\mathrm{AQD})$, 現地のアクラン州立 大学が行った。種苗は現地の養殖用種苗生産業者から購 入し，ほぼ 1 か月間の中間育成後に $0.5 \mathrm{~g}$ サイズで放流 した。種苗のウィルスチェックは AQD が行った。現 在, までに, 数十万尾規模の放流に 2 回成功し, $15 \%$ 程度の再捕を確認している。

今後は, 生育場所の特定と保護, 流通加工の改善など の漁獲物の高付加価值化などを, 住民参加によって行い ながら，意識変化を追跡する予定である。

\section{文献}

1) Hardin G. Tragedy of the commons. Science, 1968; 162: 1243-1248.

2) Gutierrez NL. Hilborn R. Defeo O. Leadership, social capital, and incentive promote successful fisheries. Nature, 2011; 470: 386-389.

3）資源保護協会.「最新版つくる漁業」(水産庁監修) 農林統 計協会, 東京. 1983 . 